\title{
FORMULASI KEBIJAKAN PIDANADENDA DAN UANG PENGGANTI DALAM PENEGAKAN TINDAK PIDANA KORUPSI DI INDONESIA
}

\author{
FORMULATION OF FINE CRIMINAL POLICIES AND \\ REPLACEMENT MONEY IN CRIMINAL ENFORCEMENT \\ CORRUPTION IN INDONESIA
}

\author{
Diding Rahmat \\ Universitas Kuningan, Indonesia \\ E-mail : didingrahmat@uniku.ac.id
}

\begin{abstract}
Indonesia is a legal state based on article 1 paragraph (3) of the 1945 Constitution, so all practices of carrying out due process of law must be based on laws and regulations. Accountability of state finances which has a detrimental or or not detrimental effect on state finances in the perspective of criminal law must be based on the principles oflegality, legal certainty, usefulness, justice, proof theory and aims to save state finances from perpetrators so that state losses can be returned with effective law, namely through a fine and substitute without jail. This study aims to determine and analyze the formulation of criminal policy fines and substitute money without substitute for imprisonment in the enforcement of criminal acts of corruption in Indonesia. This research method uses the normative juridical method that is the research method with primary, secondary and tertiary materials such as laws and regulations, journals and books. The researcher is first one; The regulation of liability for fines is only contained in Article 10, Articles 30 and 31 of the Criminal Code while in criminal acts of corruption the fine does not regulate in detail then the substitute money for convicted corruption is regulated in article 18 paragraph (1), (2) and (3) of the Law No.31 of 1999 in conjunction with Law No.20 of 2001 concerning Eradication of Corruption. Second; The need for policy formulation in the laws and regulations regarding fines and compensation money contained in the Corruption Act, particularly regarding criminal fines and replacement money so as not to be replaced by prison but by installments with a time agreement given to the perpetrators and not replaced with imprisonment according to the provisions of the law.
\end{abstract}

Keywords: Formulation, Policy, Fines, Replacement Money.

\begin{abstract}
Abstrak
Indonesia adalah negara hukum berdasarkan pasal 1 ayat (3) Undang undang Dasar 1945 maka segala praktek menjalankan due proses of law harus berdasarkan hukum dan peraturan perundang-undangan. Pertanggung jawaban keuangan negara yang berdimensi merugikan dan atau tidak merugikan keuangan negara dalam perspektif hukum pidana harus berdasarkan asas legalitas, kepastian hukum,kemanfaatan, keadilan, teori pembuktian dan bertujuan untuk menyelamatkan keuangan negara dari para pelaku sehingga kerugian negara mampu dikembalikan dengan hukum yang efektif yaitu melalui hukuman denda dan uang pengganti tanpa pengganti penjara. Penelitian ini bertujuan untuk mengetahui dan menganalisis formulasikebijakan pidana denda dan uang pengganti tanpa pengganti penjara dalam penegakan tindak pidana korupsi di Indonesia. Methode penelitian ini memakai metode yuridis normatif yaitu methode penelitian dengan bahan primer, sekunder dan tersier
\end{abstract}


seperti peraturan perundang undangan, jurnal dan buku. Peneliti berkesimpualan pertama; Pengaturan pertanggungjawaban hukuman denda hanya terdapat dalam Pasal 10, Pasal 30 dan 31 KUHP sedangkan dalam tindak pidana korupsi hukuman denda tidak mengatur secara rinci kemudian uang pengganti pada terpidana korupsi diatur dalam pasal 18 ayat (1),(2) dan (3) Undang undang No.31 tahun 1999 jo Undang Undang No.20 Tahun 2001 Tentang Pemberantasan tindak pidana korupsi. Kedua; perlu adanya Formulasi kebijakan dalam peraturan perundang undangan mengenai hukuman denda dan uang pengganti yang terdapat dalam Undang undang tindak pidana korupsi khususnya mengenai pidana denda dan uang pengganti agar tidak diganti dengan penjara tapi dengan cara di cicil dengan kesepakatan waktu yang diberikan kepada pelaku dan tidak diganti dengan hukuman penjara sebagaimana ketentuan peraturan perundang undangan.

Kata Kunci: Formulasi, Kebijakan,Denda, Uang Pengganti.

\section{PENDAHULUAN}

Tujuan Negara sebagai mana amanat alinea ke IV Pembukaan Undang Undang Dasar Negara Republik Indonesia yaitu melindungi segenap bangsa Indonesia dan seluruh tumpah darah Indonesia, memajukan kesejahteraan umum, mencerdaskan kehidupan bangsa serta ikut melaksanakan ketertiban dunia yang berdasarkan kemerdekaan, perdamaian abadi dan keadilan sosial. Berdasarkan hal diatas maka dapat di sederhanakan dalam kontek penelitian ini yang menjadi kefokusannya adalah memajukan kesejahteraan umum dan keadilan sosial. Sebagai Negara yang berdasarkan hukum berdasarkan Pasal 1 Ayat (3) UUD 1945 dan Pancasila sebagai landasan idiologi tentu nilai nilai dan orientasi bernegara harus mampu memberikan perlindungan hukum, kepastian, keadilan dan kemanfaatan bagi seluruh rakyatnya agar apa yang termaktub dalam tujuan bernegara sebagaimana diatas dapat tercapai. Salah satu faktor tidak akan tercapainya kesejahteraan sosial dan keadilan sosial adalah adanya prilaku korupsi, kolusi dan nepotisme.

Korupsi sudah berlangsung lama, sejak zaman Mesir Kuno, zaman Babilonia, Roma abad pertengahan dan bahkan sampai sekarang. Korupsi terjadi di berbagai negara di dunia, tak terkecuali di negara- negara maju sekalipun. Di negara Amerika Serikat sendiri yang sudah begitu maju masih ada praktekpraktek korupsi. Sebaliknya, pada masyarakat yang primitive di mana ikatan-ikatan sosial masih sangat kuat dan kontrol sosial yang efektif, korupsi relatif jarang terjadi. ${ }^{1}$ Korupsi merupakan kejahatan yang dipandang sebagai kejahatan tingkat tinggi, bukan saja karena kejahatan ini dilakukan secara sistematis, tetapi akibat yang ditimbulkan dari kejahatan ini paralel dan merusak seluruh sistem yang terkena virus korupsi tersebut. Karenanya, ia diperlukan sebuah penanggulangan yang menyeluruh dan sistematis baik melalui cara penal maupun non penal. Apabila selama ini cara penal tidak bisa membuat jera pelaku korupsi, maka langkah selanjutunya adalah dengan cara non penal yakni melalui moral virtue, yakni dengan membangun karakter keperibadian yang memotivasi seseorang secara intrinsik untuk tidak melakukan korupsi. ${ }^{2}$

Reformasi 1998 telah membawa perubahan terhadap tatanan penegakan hukum di Indonesia khusunya dalam bidang hukum pidana. Kehadiran Undang Undang Korupsi No.31 Tahun 1999 Jo Undang Undang No.20 Tahun 2001 tentang pemberantasan

\footnotetext{
${ }^{1}$ Bambang Hartono, Analisis Pelaksanaan Pidana Ganti Kerugian (Denda) Dalam Tindak Pidana Korupsi, Keadilan Progresif, Volume 2 Nomor 1 Maret 2011, hlm,2

${ }^{2}$ Nadir, Meretas korupsi dalam Negara Demokrasi (Sebuah Tawaran Hukum Islam Melalui Konsep Istislah), Jurnal Il-Ihkam Vol 1 Juni 2012, Hal,143-155
}

78 Jurnal IUS Kajian Hukum dan Keadilan 
tindak pidana korupsi diharapkan mampu memberikan efek jera terhadap pelaku korupsi serta untuk mengembalikan kerugian negara dari si pelaku. Tindak pidana Korupsi dikategorikan extraordinary crime (kejahatan luar biasa) karena dampak yang ditimbulkan memang luar biasa. Sebab, korupsi yang selama ini terjadi secara sistemik dan meluas, tidak hanya merugikan negara, mengganggu stabilitas dan keamanan masyarakat, serta melemahkan nilai-nilai demokrasi, etika keadilan, dan kepastian hukum, sehingga dapat membahayakan kelangsungan pembangunan, tetapi juga telah melanggar terhadap hak-hak sosial dan ekonomi masyarakat luas, yang merupakan perilaku jahat yang cenderung sulit untuk ditanggulangi dan korupsi digolongkan sebagai kejahatan yang pemberantasanya juga harus dilakukan secara luar biasa. ${ }^{3}$ Kejahatankorupsimerugikanekonomisuatunegara, menjadiekonomiberbiayatinggi ${ }^{4}$.

Upaya pemberantasan tindak pidana korupsi yang dilakukan oleh pemerintah sampai saat ini masih terus bergulir, walaupun berbagai strategi telah dilakukan, tetapi perbuatan korupsi masih tetap saja merebak di berbagai sektor kehidupan. Beberapa kalangan berpendapat bahwa terpuruknya perekonomian Indonesia dalam beberapa tahun terakhir ini, salah satu penyebabnya adalah korupsi yang telah merasuk ke seluruh lini kehidupan yang diibaratkan seperti jamur di musim penghujan, tidak saja di birokrasi atau pemerintahan tetapi juga sudah merambah ke korporasi termasuk BUMN.

Sejak 10 tahun terakhir, era reformasi birokrasi, perang terhadap korupsi terus dilakukan. Mulai dari tingkat ekskutif, legislatif maupun yudikatif korupsi terus diberantas. Peran Komisi Pemberantasan Korupsi (KPK) mengalami berbagai fase perjuangannya dalam menaklukan korupsi. Pemberantasan korupsi yang dilakukan oleh KPK mengalami berbagai peningkatan yang signifikan. Peran KPK dalam pemberantasan korupsi mempunyai signifikasi yang sangat kuat terhadap pola pemberantasannya. Disamping itu, sanksi dan efek jera bagi pelaku korupsi terus di up to date. Hal ini sebagai upaya penanganan korupsi yang lebih efektif dan efisien. Peran KPK selanjutnya tidak harus tersentralistik berada di pusat, masyarakat menantikan KPK daerah dapat terlaksana, sehingga pemberantasan korupsi dapat lebih maksimal. Dibutuhkannya lembaga KPK di daerah adalah dalam rangka untuk membangun sinergitas yang seimbang dan berimbang dalam penanganan kasus korupsi. Hal ini penting untuk ditindaklanjuti, mengingat otonomi daearah sudah berjalan cukup baik. Keberadaan otonomi daerah adalah harus menjamin keterbukaan dan transparansi dari pemerintah daerah kepada masyarakat serta pertanggungjawabannya. Begitu juga dengan pelayanan publik menjadi akses yang paling dibutuhkan oleh masyarakat dalam menerima pelayanan. Terutama dalam penanganan tehadap tindak pidana korupsi sumber daya alam. ${ }^{5}$

Penegakan hukum di satu sisi dan keadilan dimasyarakat di sisi lain diperlukan keselarasan, terutama dalam hak mendapatakan bantuan hukum bagi masyarakat dengan tidak membedabedakan ras, agama, dan golongan. Sebagaimana amanah UUD 1945 terutama Pasal 27 baik yang telah diamandemen ataupun sebelum amandemen.

\footnotetext{
${ }^{3}$ Aziz Syamsuddin, 2011, Tindak Pidana Khusus, Sinar Grafika, Jakarta, hlm. 175.

${ }^{4}$ Russel Butarbutar, Modus Operandi dan Pertangungjawaban PidanaSuap Korporasi, PJIH Volume 4 Nomor 1 Tahun 2017, hlm. 182.

${ }^{5}$ Yusrianto Kadir dan Roy Marthen Moonti, Pencegahan Korupsi Dalam Pengelolaan Dana Desa, Jurnal Ius Kajian Hukum dan Keadilan, Volume 6 No. 3, Desember 2018, hal.431
} 
Penjabaran UUD 1945 Pasal 27 dieterjemahkan ke dalam UU No. 16 Tahun 2011 Tentang bantuan hukum. Hukum dalam bentuknya ada dua yakni: Pertama,bersifat tidak tertulis dimana hukum yang demikian merupakan aturan hukum yang hidup dalam masyarakat atau yang sering dikatakan sebagai hukum adat; Kedua,hukum tertulis yakni dibuat oleh lembaga yang berwenang dan memiliki sanksi serta bersifat memaksa. Perbedaan keduannya terletak pada bentuk dan sanksinya. Bentuk hukum tidak tertulis hanya merupaka peraturan yang diturunkan secara turun temurun dan kurang memiliki sanksi yang tegas, sementara hukum tertulis selain memiliki sanksi yang tegas juga memiliki kejelasan tentang lembaga yang membuatnya. ${ }^{6}$

Hukuman yang dijatuhkan hakim dalam tindak pidana korupsi belum mampu memberikan efek jera dan hasil yang memuaskan dalam pengembalian kerugian keuangan negara yang ada, hukuman denda dan uang pengganti sebagai bagian dari hukuman yang diberlakukan terhadap terpidana belum memiliki hasil maksimalterhadappenegakanhukumitusendiri. Pelaksanaan hukuman denda dan pembayaran uang pengganti dalam tindak pidana korupsi dapat dikatakan belum efektifdantidakmempunyaiefekjera. Hal ini dapat terlihat dengan keadaan terpidana yang tidak mampu membayar, tidak mempunyai harta benda guna menutup pembayaran uang pengganti yang dijatuhkanolehpengadilan, adanya surat pernyataannya yang menerangkan tidak mampu membayar uang pengganti dan mampu melaksanakan pidana subsider. ${ }^{7}$

Pidana denda dalam tindak pidana korupsi dirasa terlalu kecil ancamannya mulai dari pidana denda paling sedikit Rp 200.000.000 (dua ratus juta rupiah) sampai ke pidana denda maksimal Rp. 1.000.000.000 (satu miliar rupiah). Pidana denda juga hanya sebagai hukuman alternatif yang memungkinkan jika pelaku korupsi tidak dapat membayar denda tersebut, hanyalah dikenakan pidana kurungan yang maksimumnya hanya 6 (enam) atau 8 (delapan) bulan. Kemudian, Pidana denda merupakan satusatunya pidana yang dapat dan dibayar atau ditanggung oleh orang lain selain terpidana. Tidakkah dengan demikian para koruptor dapat dengan leluasa berbuat tindak pidana korupsi sebab ia merasa bahwa pertanggungan jawab akan dipikul oleh orang lain dan hasil kurupsi tetap dapat dinikmati dengan tidak perlu khawatir harta benda atau kekayaannya akan dirampas atau disita. Walaupun hakim dapat pula menjatuhkan pidana tambahan, namun yang dapat dirampas hanyalah barang-barang yang diduga diperoleh dari hasil kejahatan atau sengaja dipergunakan untuk melakukan kejahatan. ${ }^{8}$

Pengembalian kerugian negara merupakan salah satu tujuan dasar dari pemberantasan tindak pidana korupsi, termasuk pemidanaan terhadap pelaku korporasi. Sistem pemidanaan dalam undang undang tindak pidana korupsi yang bersifat primum remedium dan menggunakan retributif justice, dalam prakteknya tidak berhasil secara optimal mengembalikan kerugian keuangan negara. ${ }^{9}$ Maka berkaitan dengan hal demikian maka perlu adanya formulasi untuk mencari formulasi kebijakan pidana denda dan uang pengganti pada terpidana korupsi di Indonesia. Sehingga dengan demikian akan terdapat solusi yang tepat dalam penegakan tindak pidana korupsi dalam putusan sanki

\footnotetext{
${ }^{6}$ Diding Rahmat, Implementasi Kebijakan Program Bantuan Hukum Bagi Masyarakat Tidak Mampu Di Kabupaten Kuningan, Jurnal Unifikasi, ISSN 2354-5976 Vol. 04 Nomor 01 Januari 2017, hal.36

${ }^{7}$ Ade Paul Lukas, Efektivitas Pidana Pembayaran Uang Pengganti Dalam Tindak Pidana Korupsi(Studi Putusan Tindak Pidana Korupsi di Pengadilan Negeri Purwokerto), Jurnal Dinamika HukumVol. 10 No. 2 Mei 2010, hlm.81

${ }^{8}$ Wahyuningsih, Ketentuan Pidana Denda Dalam Kejahatan Korupsi Di Tingkat Extraordinary Crime, alJinâyah: Jurnal Hukum Pidana Islam Volume 1 , Nomor 1 , Juni 2015,hlm.105

${ }_{9}^{9}$ Budi Suhariyanto, Restoratif justice dalam pemidanaan korporasi pelaku korupsi demi optimalisasi kerugian negara, jurnal rechvinding, volume 5, nomor 3, Desember 2016, hlm,421
}

80 Jurnal IUS Kajian Hukum dan Keadilan 
denda dan uang pengganti sebagai mana yang di inginkan dan di cita citakan, maka berdasarkan uraian diatas penulis tertarik untuk membahas terkait alternatif pidana denda dan uang pengganti tanpa pengganti penjara.

Metode penelitian yang digunakan dalam penelitian ini adalah penelitan hukum normatif atau kepustakaan mengingat masalah yang diteliti adalah menyangkut bahan hukum seperti peraturan perundang undangan dan literatur hukum. Sedangkan metode analisa data dalam penelitian ini menggunakan analisa normatif kualitatif. Analisa Normatif adalah penelitian yang mendasarkan kepada peraturan perundang undangan yang berlaku sebagai hukum positif sedangkan kualitatif merupakan tatacara yang digunakan dan dipusatkan guna memperoleh data deskriptif.Penelitian ini bertujuan untuk mengetahui dan menganalisis efektifitas pertanggungjawaban hukuman denda pada terpidana korupsi. Methode penelitian ini memakai metode yuridis normatif yaitu methode penelitian dengan bahan primer, sekunder dan tersier seperti peraturan perundang undangan, jurnal dan buku. Bahan hukum primer yang digunakan yaitu : Undang undang Dasar NRI 1945, Undang Undang No.31 Tahun 1999 Jo. Undang undang No.20 Tahun 2001 Tentang Tindak Pidana Korupsi, Kitab Undang-Undang Hukum Pidana (KUHP).

\section{PEMBAHASAN}

\section{Pengaturan Hukuman Denda dan Uang Pengganti pada Tindak Pidana Korupsi saat ini}

Pengaturan pidana atau hukuman denda Berdasarkan Undang undang Nomor 31 Tahun 1999 Jo. Undang undang Nomor 20 Tahun 2001 Tentang Tindak Pidana Korupsi, tidak mengatur secara rinci hanya terdapat dalam pasal pasal mengenai perbutan perbuatan yang memenuhi rumusan pasal dalam tindak pidana koruspi yang di dalamnya terdapat ketentuan pidana penjara dan denda.

Pengaturan hukuman denda dalam tindak pidana korupsi lebih banyak memakai dasar hukum yang terdapat didalam KUHP yakni yang terdapat pada Pasal 10, Pasal 30 dan Pasal 31 KUHP, dalam Pasal 10 KUHAP pidana denda masuk dalam katagori pidana pokok selain pidana mati, kurungan, penjara dan pidana tutupan sedang pidana tambahan yaitu pencabutan hak hak tertentu, perampasan barang barang tertentu dan pengumuman putusan hakim.

Sedangkan Pasal 30 dan Pasal 31 KUHP mengenai tekhnis pelaksanaan pidana denda yaitu Pasal 30 berbunyi ;

1) Banyaknya denda sekurang kurangnya 25 sen (250,-)

2) Jikadijatuhkanhukumandendadandendatidakdibayar,makadigantidengankurungan.

3) Lamanya hukuman kurungan pengganti itu sekurang-kurangnya satu hari dan selamalamanya enam bulan.

4) Lamanya kurungan ini ditetapkan begitu rupa, bahwa harga setengah rupiah atau kurang diganti dengan satu hari, bagi denda yang lebih besar daripada itu, maka bagi tiap-tiap setengah rupiah diganti tidak lebih daripada satu hari, dan bagi sisanya yang tidak cukup setengah rupiah, lamanya pun satu hari.

5) Jikaadapemberatandendakarenaperbarenganataupengulanganataukarenaketentuan pasal 52 dan 52a, maka kurungan pengganti paling lama dapat menjadi delapan bulan.

Sedangkan Pasal 31 berbunyi ;(1) Terpidana dapat menjalani pidana kurungan pengganti tanpa menunggu batas waktu pembayaran denda. (2) Ia selalu berwenang membebaskan dirinya dari pidana kurungan pengganti dengan membayar dendanya. 
(3) Pembayaran sebagian dari pidana denda, baik sebelum maupun sesudah mulai menjalani pidana kurungan yang seimbang dengan bagian yang dibayarnya.

Berdasarkan hal diatas maka dasar hukum pengaturan pidana denda terdapat dalam pasal 10, Pasal 30 dan Pasal 31 KUHP sedangkan dalam undang undang tindak pidana korupsi tidak ada aturan yang sepesifik mengatur tentang pidana denda hanya terdapat didalam unsur unsur pasal yang didalamnya memuat sanksi penjara dan denda.

Berbeda dengan uang pengganti yang merupakan pidana tambahan selain yang terdapat dalam ketentuan Pasal 10 KUHP, uang pengganti diatur dalam Pasal 18 ayat (1), (2) dan (3) undang undang tindak pidana korupsi yaitu undang undang No.31 Tahun 1999 Jo Undang Undang No.20 Tahun 2001 Tentang Tindak Pidana Korupsi yaitu :

(1) Selain pidana tambahan sebagaimana dimaksud dalam Kitab Undang Undang Hukum

Pidana sebagai pidana tambahan adalah :

a. perampasan barang bergerak yang berwujud atau yang tidak berwujud atau barang tidak bergerak yang digunakan untuk atau yang diperoleh dari tindak pidana korupsi, termasuk perusahaan milik terpidana di mana tindak pidana korupsi dilakukan, begitu pula harga dari barang yang menggantikan barang-barang tersebut;

b. pembayaran uang pengganti yang jumlahnya sebanyak-banyaknya sama dengan harta benda yang diperoleh dari tindak pidana korupsi.

c. penutupan seluruh atau sebagian perusahaan untuk waktu paling lama 1 (satu) tahun;

d. pencabutan seluruh atau sebagian hak-hak tertentu atau penghapusan seluruh atau sebagian keuntungan tertentu, yang telah atau dapat diberikan oleh Pemerintah kepada terpidana;

(2) Jika terpidana tidak membayar uang pengganti sebagaimana dimaksud dalam ayat (1) huruf b paling lama dalam waktu 1 (satu) bulan sesudah putusan pengadilan yang telah memperoleh kekuatan hukum tetap, maka Undang-undang ini dan lamanya pidana tersebut sudah ditentukan dalam putusan pengadilan.harta bendanya dapat disita oleh jaksa dan dilelang untuk menutupi uang pengganti tersebut.

(3) Dalam hal terpidana tidak mempunyai harta benda yang mencukupi untuk membayar uang pengganti sebagaimana dimaksud dalam ayat (1) huruf b, maka dipidana dengan pidana penjara yanglamanya tidak melebihiancaman maksimum daripidana pokoknya sesuai dengan ketentuan.

\section{Formulasi Kebijakan Pidana Denda dan Uang Pengganti Dalam Penegakan Tin- dak Pidana Koruspi}

Menurut Barda Nawai Arief Perkembangan ilmu hukum pada umumnya dan praktiknya seringkali menimbulkan masalah yang menyangkut keberadaan kaidah hukum dan efektivitas kaidah-kaidah hukum dengan menge-tengahkan efektivitas hukum. Artinya efektivitas hukum akan disoroti dari tujuan yang ingin di capai. Efektivitas mengandung arti "keefektif-an" (efectiveness) pengaruh/efek keberhasilan, atau kemanjuran/ kemujaraban. ${ }^{10}$ Teori efektivitas hukum menurut Soerjono Soekanto adalah bahwa efektif atau tidaknya suatu hukum ditentukan oleh 5 (lima) faktor, yaitu : ${ }^{11}$

1. Faktor hukumnya sendiri (undang-undang).

\footnotetext{
${ }^{10}$ Barda Nawawi Arief, 2003, Kapita Selekta Hukum Pidana, Citra Aditya Bakti, Bandung, hlm. 85

${ }^{11}$ Soerjono Soekanto, 2008, Faktor-Faktor yang Mempengaruhi Penegakan Hukum, PT. Raja Grafindo Persada, Jakarta, hlm. 8.
} 
2. Faktor penegak hukum, yakni pihak-pihak yang membentuk maupun menerapkan hukum.

3. Faktor sarana atau fasilitas yang mendukung penegakan hukum.

4. Faktor masyarakat, yakni lingkungan dimana hukum tersebutberlaku atau diterapkan.

5. Faktor kebudayaan, yakni sebagai hasil karya, cipta dan rasa yang didasarkan pada karsa manusia di dalam pergaulan hidup.

Sehubungan dengan faktor masyarakat yang ikut mempengaruhi penegakan hukum ini, apabila dikaitkan dengan pendapat Friedman tentang unsur-unsur dalam sistem hukum yang salah satu unsurnya adalah "budaya hukum" yaitu sikap-sikap dan nilai yang berhubungan dengan hukum, yang datangnya dari rakyat atau pemakai jasa hukum. ${ }^{12}$

Kata " Korup " berarti buruk, rusak dan busuk, suka memakai barang (uang) yang dipercayakan kepadanya, dapat disogok (memakai kekuasaannya untuk kepentingan pribadi. Korupsi menurut kamus besar bahasa indonesia adalah tindakan penyelewengan atau penggelapan keuangan negara atau perusahaan untuk kepentingan pribadi atau orang lain. ${ }^{13}$ Korupsi dalam bahasa Latin disebut Corruptio - corruptus, dalam Bahasa Indonesia disebut corruptie, dalam Bahasa Inggris disebut corruption, dan dalam Bahasa Sansekerta yang tertuang dalam Naskah Kuno Negara Kertagama arti harfiah corrupt menunjukkan kepada perbuatan yang rusak, busuk, bejad, tidak jujur yang disangkut pautkan dengan keuangan. ${ }^{14}$ Sedangkan menurut Pasal 2 ayat (1) Undang Undang Nomor 31 Tahun 1999 jo Undang Undang Nomor 20 Tahun 2001 Tentang Pemberantasan Tindak Pidana Korupsi menyebutkan bahwa yang dimaksud tindak pidana korupsi adalah setiap orang yang secara melawan hukum melakukan perbuatan memperkaya diri sendiri atau orang lain atau suatu korporasi yang dapat merugikan keuangan negara atau perekonomian negara. Berdasarkan pasal diatas maka terdapat unsur unusr delik tindak pidana sebagai berikut :

1. Setiap Orang;

2. Yang melakukan perbuatan melawan hukum;

3. Memperkaya diri sendiri, orang lain atau suatu korporasi;

4. Dapat merugikan keuangan negara atau perekonomian negara.

Korupsi merupakan suatu bentuk perbuatan melawan hukum yang merugikan keuangan atau perekonomian negara. Adapun yang dimaksud dengan tindakan melawan hukum adalah suatu perbuatan atau tidak berbuat sesuatu yang mengakibatkan timbulnya kerugian bagi orang lain. Dimana perbuatan atau tidak berbuat tersebut merupakan perbuatan sengaja atau merupakan suatu kecelakaan. ${ }^{15}$

Secara kultural dan stuktural memberantas korupsi adalah mensosialisasikan nilai baru bahwa korupsi merupakan sebuah tidakan yang beresiko tinggi dan bernilai rendah, dan akan dikenkan pembuktian terbalik bahwa harta yang diperolehnya adalah barang yang halal. ${ }^{16}$

Apabila dibandingkan dengan sistem pemidanaan di negeri Belanda, maka dapat dikatakan bahwa pola pemidanaan di Indonesia hanya mengenal pidana denda yang dikenakan oleh pengadilan. Sedangkan Belanda mengenal sanksi-sanksi ekstra pengadilan yang dapat melakukan transaksi denda yang harus dibayar agar suatu kasus

\footnotetext{
${ }^{12}$ Abdul Manan, 2005, Aspek-aspek Pengubah Hukum, Prenada Media Group, Jakarta, hlm. 9

${ }^{13}$ https://kbbi.web.id/korupsi diunduh pada tanggal 17 Sepetember pukul 19.00

${ }^{14}$ Sudarto, 1996, Hukum dan Hukum Pidana, Cetakan Keempat, Alumni, Bandung, hlm. 115.

${ }^{15}$ Munir Fu’ady, 2005, Perbuatan Melawan Hukum, Bandung: PT. Citra Aditya Bhakti,hlm. 4

${ }^{16}$ Nadir, Meretas korupsi dalam Negara Demokrasi (Sebuah Tawaran Hukum Islam Melalui Konsep Istislah), Jurnal Il-Ihkam Vol 1 Juni 2012, Hal,143-155
} 
tidak diteruskan ke pengadilan, yaitu: sanksi-sanksi ekstra yuridis berupa transaksi polisi, transaksi dengan kantor kejaksaan, pembebasan bersyarat, apabila telah dilakukan penuntutan. ${ }^{17}$

Efektivitas pidana denda tidak memberikan efek jera bagi pelaku tindak pidana korupsi, karena pidana denda yang dijatuhkan kepada pelaku tindak pidana korupsi dapat diganti dengan pidana kurungan dan lamanya masa kurungan tidak sesuai dengan jumlah kerugian keuangan negara akibat perbuatan pelaku tindak pidana korupsi tersebut. Pidana ganti kerugian (denda) tidak memberikan efek jera bagi pelaku tindak pidana korupsi, karena pidana denda yang dijatuhkan kepada pelaku tindak pidana korupsi masih terlalu rendah jumlahnya.

Pidana denda adalah suatu hukuman, berdasarkan ketentuan KUHP yaitu wajib membayar sejumlah uang yang di tetapkan dalam putusan pengadilan kepada negara, tidak dapat mendayagunakan keberatan atau perlawanan dalam konteks hukum keperdataan terhadap negara. ${ }^{18}$ Menurut Undang Undang No. 31 Tahun 1999 jo. Undang Undang No. 20 Tahun 2001, bentuk sanksi pidana yang dapat dikenakan kepada pelaku tindak pidana korupsi adalah pidana penjara dan pidana denda. ${ }^{19}$ Ketentuan pidana denda dalam kejahatan korupsi ditingkatextraordinary crime sudah diatur dalam Undang Undang No. 20 Tahun 2001 tentang Pemberantasan Tindak Pidana Korupsi akan tetapi penerapannya belum terlalu efektif karena hakim lebihbanyak memilih pidana penjara menjadi pidana pokok, padahal pidana denda mempunyai maanfaat lebih baik dari pada sanksi pidana perampasan dan memiliki efektivitas dalam membuat jera pelaku korupsi. ${ }^{20}$ Dalam penelitian yang lain formulasi pidana denda dalam hukum pidana positif belum sesuai dengan modernisasi pemidanaan. Pengaturan pidana denda di dalam hukum pidana positif tertinggal jauh bilamana dibandingkan dengan pemberlakuan denda di berbagai negara. Kemudian Denda yang dikenakan bagi pelaku tindak pidana korupsi tidak sesuai dengan ketentuan denda yang ada di dalam undang-undang tindak pidana korupsi. Walaupun sebagian besar seluruh perkara korupsi terbuksi secara sah dan meyakinkan. ${ }^{21}$

Namun sebagian besar seluruh perkara korupsi terbukti sah dan meyakinkan, terutama dalam Pengadilan Tindak Pidana Korupsi yang ditangani oleh KPK cenderung sulit mengeksekusi pidana denda dan ganti kerugian dalam tindak pidana korupsi dan menjadi masalah yang belum dapat diselesaikan. Penjatuhan pidana denda yang tinggi tidak akan efektifdalampelaksanaannya mengingat adanya ketentuan bilamana denda tidak dibayar akan diganti dengan kurungan, sebagaimana termaktub dalam pasal 30 KUHP. Selain itu, ketentuan pasal 30 KUHP tidak mengatur batas waktu yang pasti kapan denda itu harus dibayar. Demikian juga tidak ada ketentuan mengenai tindakantindakan lain yang menjamin agar terpidana dapat dipaksa untuk membayar dendanya. Artinya, walaupun hakim menjatuhkan pidana denda tinggi, pelaku tindak pidana korupsi cenderung memilih hukuman kurungan selama enam (6) bulan atau delapan (8) bulan jika terdapat pemberatan denda daripada harus membayar denda yang dijatuhkan pengadilan kepadanya. Oleh karena itu, ketentuan tersebut seharusnya disimpangi dan

\footnotetext{
${ }^{17}$ Soedjono D, 1989, Sistem Peradilan Pidana Peraturan Umum dan Delik-Delik Khusus, RajawaliPers, Jakarta, hlm.76.

18 Jan Remmelink, 2003, Hukum Pidana: Komentar atas Pasal-Pasal Terpenting dalam Kitab Undang Undang Hukum Pidana Belanda dan Padanannya Dalam Kitab Undang-Undang Hukum Pidana Indonesia, , PT Gramedia, Jakarta, hlm. 485

${ }^{19}$ Evi Hartati, Tindak Pidana Korupsi, Sinar Grafika, Jakarta, 2007,hlm. 12

${ }^{20}$ Wahyuningsih, Ketentuan Pidana Denda Dalam Kejahatan Korupsi Di Tingkat Extraordinary Crime, alJinâyah, Jurnal Hukum Pidana Islam Volume 1 , Nomor 1, Juni 2015,hlm.105

${ }^{21}$ Syaiful Bakhri, Kebijakan Legislatif tentang Pidana Denda dan Penerapannya dalam Upaya Penanggulangan Tindak Korupsi, Jurnal Hukum No. 2 Vol. 17 April 2010,hlm. 317 - 334
} 
diganti dengan membayar denda dari harta kekayaan pelaku maupun keluarganya, baik melalui cicilan maupun dengan cara lain. Jalan keluarnya adalah menciptakan adanya ketentuan atau suatu peraturan yang bersifat memaksa sehingga terpidana mau tak mau harus membayar denda tersebut. Misalnya KPK diberi wewenang untuk melelang di muka umum barang yang sudah disita (bukan yang dirampas) kemudian memotong uang denda dari hasil lelang tersebut. Hal ini dapat dijalankan apabila terpidana sesudah diberikan waktu yang lama tapi tetap tidak mau membayar denda. Kalau barang yang akan disita sudah tidak ada lagi, barulah diterapkan pengganti denda. ${ }^{22}$

Pidana denda pada tindak pidana korupsi dalam pelaksanaanya berjalan kurang maksimal. Selain pidanan denda hakim dalam putusanya memberika pidana tambahan berupa pidana hukuman ganti kerugian. Namun dalam kenyataan pidana ganti kerugian tidak memberikan efek jera bagi pelaku tindak pidana korupsi, hal ini terbukti dengan masih banyaknya tindak pidana korupsi yang terjadi di Indonesia. ${ }^{23}$ Pengaturan hukuman denda dalam undang undang tindak pidana korupsi misalnya yang terdapat dalam pasal 2 ayat (1) yang berbunyi sebagai berikut :

"Setiap orang yang secara melawan hukum melakukan perbuatan memperkaya diri sendiri atau orang lain yang suatu korporasi yang dapat merugikan keuangan negara atau perekonomian negara, dipidana dengan pidana penjara seumur hidup atau pidana penjara paling singkat 4 (empat) tahun dan paling lama 20 (dua puluh) tahun dan denda paling sedikit $R p$. 200.000.000.00 (dua ratus juta rupiah) dan paling banyak Rp. 1.000.000.000,00 (satu miliar rupiah)"

Berdasarkan hal diatas pengaturan pidana denda terkesan tidak serius dikarenakan hukumannya bersifat minimalis, hal ini terlihat dengan hukuman denda yang sangat kecil sekali nilainya yaitu antara 200.000.0000 (dua ratus juta rupiah) sebagai denda minimum dan 1.000.0000.000 ( satu miliyar rupiah) sebagai denda maksimun, Selain hukuman yang minimalis rata rata putusan hakim dalam pelaksanaan pidana denda acap kali diganti dengan hukuman penjara, penggantian hukuman denda dengan penjara dalam kontek tujuan pemidanaan tindak pidana korupsi yang harus mengembalikan kerugian uang negara atau memberikan efek jera tidak tercapai dengan mengganti hukuman denda dengan penjara, padahal dalam sistem pelaksanaan pidana denda dalam KUHP mengandung berbagai kelemahan menurut Nawawi Arief yaitu ${ }^{24}$

1. Tidakadanyaketentuanmengenaitindakantindakanlainuntukmenjaminpelaksanaan pidana denda, misalnya dengan merampas atau menyita harta benda atau kekayaan, kecuali dengan kurunagan uang pengganti;

2. Maksimum kurungan pengganti hanya 6 bulan yang dapat menjadi 8 bulan apabila ada pemberatan denda, walaupun pidana denda yang diancamkan atau dijatuhkan oleh hakim cukup tinggi sampai puluhan juta;

3. Tidak ada pedoman atau kriteria untuk menjatuhkan pidana denda, baik secara umum maupun untuk hal khusus (misalnya untuk denda yang dijatuhkan terhadap anak yang belum dewasa, yang belum bekerja atau masih dalam tanggungan orang tua;

Selain hal diatas perlu adanya formulasi kebijakan dalam pelaksanaan pidana denda dengan tidak mengganti dengan pidana penjara karena dirasa tidak evektif hal ini dengan banyaknya pelaku tindak pidana korupsi yang lebih memilih mengganti pidana denda

${ }^{22}$ Ninik suparni dalam Wahyuningsih, Ketentuan Pidana Denda Dalam Kejahatan Korupsi Di Tingkat Extraordinary Crime, al-Jinâyah: Jurnal Hukum Pidana Islam Volume 1 , Nomor 1 , Juni 2015,hlm.105

${ }_{23}$ Bambang Hartono, Analisis Pelaksanaan Pidana Ganti Kerugian(Denda) Dalam Tindak Pidana Korupsi,Keadilan Progresif Volume 2 Nomor 1 Maret 2011,hlm.13

${ }^{24}$ Indung Wijayanto,Kebijakan Pidana denda di KUHP dalam Sistem Pemidanaan Indonesia,Jurnal Pandecta, Volume 10 Nomor 2 Desember 2015, hal.249 
dengan penjara hanya saja perlu ada rumusan perubahan atau formulasi ketentuan dalam undang undang tindak pidana korupsi atau KUHP yang mengtur mengenai pidana denda.

Begitupun dengan pidana hukuman uang pengganti yang terdapat dalam Pasal 18 ayat (1), (2), dan (3) Undang Undang No.31 Tahun 1999 Jo Undang Undang No.20 Tahun 2001 Tentang Tindak Pidana Korupsi dirasa dalam pelaksanaanya tidak ada evektif dikarenakan terkadang untuk menelusuri harta kekayaan pelaku sangat sulit atau pelaku berusaha menyembunyikan hartanyta, hal inilah yang harus dicarikan formulasi kebijakan dalam penggembalian kerugian negara secara maksimal dengan tidak mendasarkan pada ketentuan Pasal 18 ayat (2) dan (3) yag ccenderung lebih memilih mengganti dengan hukuman penjara :

Teori efektivitas hukum menurut Soerjono Soekanto adalah bahwa efektif atau tidaknya suatu hukum ditentukan oleh 5 (lima) faktor, yaitu : ${ }^{25}$

1. Faktor hukumnya sendiri (undang-undang).

2. Faktor penegak hukum, yakni pihak-pihak yang membentuk maupun menerapkan hukum.

3. Faktor sarana atau fasilitas yang mendukung penegakan hukum.

4. Faktor masyarakat, yakni lingkungan dimana hukum tersebutberlaku atau diterapkan.

5. Faktor kebudayaan, yakni sebagai hasil karya, cipta dan rasa yang didasarkan pada karsa manusia di dalam pergaulan hidup.

Berdasarkan teori hukum diatas penulis beranggapan bahwa faktor faktor tidak evektifnya pelaksanaan hukuman denda dan uang pengganti diatas dapat dilihat dari sisi undang undang dan aparat hukumnya yaitu sebagi berikut : Pertama, undang undang korupsi yaitu Undang Undang No.31 Tahun 1999 Jo Undang Undang No.20 Tahun 2001 Tentang Tindak Pidana Korupsi tidak secara mendalam dan konkrit mengatur tentang pidana denda dan uang pengganti hal ini membuat pelaksanaan penegakan sanksi denda dan uang pengganti tidak tegas dan tidak kontekstual dalam memberikan waktu kepada pelaku tindak pidana korupsi kedepan harus ada formulasi waktu yang diberikan kepada pelaku untuk membayar denda dan uang pengganti dengan cara di cicil kenegara sesuai dengan kemampuan pelaku sampai dengan lunas meskipun sudah tidak menjalani hukuman;Kedua, pidana denda dan uang pengganti dalam rumusan pasal cenderung mengganti dengan penjara sehingga dalam definisnya tidak menggambarkan suatu bentuk pidana yang dapat memberatkan pelaku dan pelaku cenderung memilih mengganti nya dengan penjara dan;ketiga, hakim dalam putusan denda dan uang pengganti tidak kontekstual dan progresif.

\section{SIMPULAN}

Berdasarkan uraian diatas maka penulis menarik simpulan terkait dengan hukuman denda dan uang pengganti yang berlaku saat ini, yaitu :

1. Pengaturan hukuman denda dan uang pengganti pada terpidana korupsi diatur dalam Undang undang Korupsi No.31 tahun 1999 jo Undang Undang No.20 Tahun 2001 Tentang Pemberantasan Tindak Pidana Korupsi terdapat dalam Pasal 18Ayat (1), (2) dan (3) sedangkan dalam tindak pidana umum diatur dalam pasal 10, 30 dan 31 KUHP. Perlu adanya rekontruksi rumusan Pasal 30 ayat (2) menjadi jika pidana denda tidak dibayar, terpidana harus membayarnya samapai dengan lunas dengan cara mencicil sesuai dengan kemampuanya dan dapat diwariskan oleh ahli waris jika terpidana

${ }^{25}$ Soerjono Soekanto, Faktor-Faktor yang Mempengaruhi Penegakan Hukum ,Jakarta: PT. Raja Grafindo Persada, 2008, hlm. 8.

86 Jurnal IUS Kajian Hukum dan Keadilan 
meninggal dunia. Sedangkan rekontruksi atau formulasi uang penggant dalam Pasal 18 ayat (3) Undang Undang No.31 Tahun 1999 Jo Undang undang No.20 Tahun 2001 Tentang Tindak Pidana Korupsi menjadi Dalam hal terpidana tidak mempunyai harta benda yang mencukupi untuk membayar uang pengganti sebagaimna dimaksud dalam ayat (1) hurup b, maka terpidana wajib mencicil kekurangan uang pengganti tersebut selama atau sesudah menjalani pidananya sampai lunas dan apabila terpidana meninggal dunia, kewajiban penggantian di berikan kepada ahli warisnya.

2. Formulasi kebijakan pidana denda dan uang pengganti dalam penegakan hukum tindak pidanakorupsidiindonesiadilihatdariduasisi, yaitu;Pertama, sisiperaturanperundang undanganya yang kurang responsif khusunya dimana dalam undang undang tersebut tidak memberikan alternatif hukuman pengganti denda dan uang pengganti selain pidana penjara, sehingga perlu adanya kebijakan alternatif seperti menyicil secara berkala sampai lunas sesuai dengan kemampuan dan keingaina pelaku meskipun sudah selesai menjalani hukuman penjara atau hukuman denda dan uang pengganti menjadi pidana yang berbentuk hutang pelaku terhdap negara yang harus dibayar dan dapat diwariskan oleh ahli warisnya apabila pelaku meninggal ; Kedua, aparat hukumnyakhususnyahakimharusmampumelakukantrobosanhukumataupenemuan hukum terutama hukum responsif dalam memutuskan hukuman denda dan uang pengganti pada terpidana korupsi agar tujuan filosofis penegakan hukum korupsi yaitu mengembalikan kerugian negara dan efek jera dapat tercapai dan berdampak pada kesejahteraan dan keadilan sosial bagi rakyat indonesia; Ketiga, Hukuman denda dan uang pengganti yang di ganti dengan penjara tidak evektif terhadap pemberantasan korupsi sehingga perlunya perubahan pasal yang mengharuskan narapidana tindak pidana korupsi mengganti dengan uang secara bertahap sampai lunas dan tidak boleh diganti dengan penjara.

\section{DAFTAR PUSTAKA}

\section{Buku}

Abdul Manan, (2005), Aspek-aspek Pengubah Hukum, Prenada Media Group, Yogyakarta. Aziz Syamsuddin, (2011), Tindak Pidana Khusus, Sinar Grafika, Jakarta.

Barda Nawawi Arief, 2003, Kapita Selekta Hukum Pidana, Citra Aditya Bakti, Bandung. Evi Hartati, (2007), Tindak Pidana Korupsi, Sinar Grafika, Jakarta.

Jan Remmelink, 2003, Hukum Pidana: Komentar atas Pasal-Pasal Terpenting dalam Kitab Undang Undang Hukum Pidana Belanda dan Padanannya Dalam Kitab Undang-Undang Hukum Pidana Indonesia, PT Gramedia Jakarta.

Moeljatno, (2008), KUHP, PT Bumi Aksara, Jakarta.

Munir Fu'ady, (2005), Perbuatan Melawan Hukum, PT. Citra Aditya Bhakti, Bandung.

Soerjono Soekanto, (2008), Faktor-Faktor yang Mempengaruhi Penegakan Hukum, PT. Raja Grafindo Persada, Jakarta

Soedjono D, (1989), Sistem Peradilan Pidana Peraturan Umum dan Delik-Delik Khusus, Rajawali Pers, Jakarta,.

Sudarto, (1996), Hukum dan Hukum Pidana, Cetakan Keempat Alumni, Bandung. 


\section{Jurnal}

Ade Paul Lukas, (2010), Efektivitas Pidana Pembayaran Uang PenggantiDalam Tindak Pidana Korupsi(Studi Putusan Tindak Pidana Korupsi di Pengadilan Negeri Purwokerto), Jurnal Dinamika Hukum Vol. 10 No. 2 Mei.

Bambang Hartono, (2011) Analisis Pelaksanaan Pidana Ganti Kerugian(Denda) Dalam Tindak Pidana Korupsi, Keadilan Progresif, Volume 2 Nomor 1 Maret.

Budi Suhariyanto, (2016) Restoratif justice dalam pemidanaan korporasi pelaku korupsi demi optimalisasi kerugian negara, jurnal rechvinding, volume 5, nomor 3, Desember.

Diding Rahmat, (2017), Implementasi Kebijakan Program Bantuan Hukum Bagi Masyarakat Tidak Mampu Di Kabupaten Kuningan, Jurnal Unifikasi, ISSN 2354-5976 Vol. 04 Nomor 01 Januari.

Indung Wijayanto, (2015), Kebijakan Pidana denda di KUHP dalam Sistem Pemidanaan Indonesia, Jurnal Pandecta, Volume 10 Nomor 2 Desember.

Nadir, (2012), Meretas korupsi dalam Negara Demokrasi (Sebuah Tawaran Hukum Islam Melalui Konsep Istislah), Jurnal Il-Ihkam, Vol 1 Juni.

RusselButarbutar,(2017),ModusOperandidanPertangungjawabanPidanaSuapKorporasi, PJIH Volume 4 Nomor 1.

Syaiful Bakhri, (2010), Kebijakan Legislatif tentang Pidana Denda dan Penerapannya dalam Upaya Penanggulangan Tindak Korupsi, Jurnal Hukum, No. 2 Vol. 17 April.

Wahyuningsih, (2015), Ketentuan Pidana Denda Dalam Kejahatan Korupsi Di Tingkat Extraordinary Crime, al-Jinâyah: Jurnal Hukum Pidana Islam, Volume 1 , Nomor 1 , Juni.

Yusrianto Kadir dan Roy Marthen Moonti, (2018), Pencegahan Korupsi Dalam Pengelolaan Dana Desa, Jurnal Ius Kajian Hukum dan Keadilan, Volume 6 No. 3, Desember. 